\title{
Recent Trends in the Philosophy of Time: an Introduction to Time and Reality $\mathrm{I}^{1}$
}

\author{
Emiliano Boccardi \\ University of Campinas-UNICAMP \\ Center for Logic, Epistemology and History of Science \\ Rua Sérgio Buarque de Holanda, 251 - Cidade Universitária, \\ Campinas - SP, 13083-859 \\ Brazil \\ emiliano.boccardi@gmail.com
}

Article info

CDD: 115

Received: 24.11.2016; Accepted: 24.11.2016

DOI: http://dx.doi.org/10.1590/0100-6045.2016.V39N4.EB

\author{
Keywords: \\ Philosophy of Time \\ Tense Realism \\ Passage of time \\ A-theory of time \\ McTaggart
}

\begin{abstract}
This essay is an introduction to Time and Reality I, the first part of a special issue dedicated to the philosophy of time. Here I outline a number of new trends in philosophical theorizing about time, detailing how the various contributions fit into the picture. I argue that there has been a potentially misleading tendency to separate the debate over the passage of time from the debate over the reality of tense. This has obscured a number of interesting philosophical questions. One of the aims of this volume is to bring these two issues together, where they belong. I argue that many contributions to it go in the right direction. The contributions to this volume also establish uncharted philosophical junctures between Metaphysics, Aesthetics, Morality, and the Philosophy of Mind.
\end{abstract}

\footnotetext{
${ }_{1}$ Reasearch for this paper and collection was supported by grant $2015 / 20138-2$ from FAPESP (Brazil).
}

Manuscrito - Rev. Int. Fil. Campinas, v. 39, n. 4, pp. 5- 34, out.-dez. 2016. 


\section{Introduction}

On April 6, 1922 the physicist Albert Einstein and the philosopher Henri Bergson debated each other's view of time at a meeting of the Societe française de philosophie in Paris. Einstein had convinced himself that his theory of relativity, whose worldwide acceptance was gaining momentum in those years, mandated a view of reality as "static". The passage of time, just like the distinction between past, present and future events, was to be regarded as a "stubbornly persistent illusion".

Bergson accused Einstein of unduly "spatializing" time, leaving out its most distinguishing dynamical feature:

Each of the successive states of [Einstein's] universe will be an instantaneous image, taking up the whole plane and comprising the totality of objects, all flat, of which this universe is made. The plane will therefore be like a screen upon which the cinematography of the universe would be run off, with the difference however that here there is no cinematography external to the screen, no photography projected from without. ${ }^{2}$

Most analytic philosophers during the first half of the $20^{\text {th }}$ Century sided with the physicist. One of Bergson's fiercest critics was Bertrand Russell, who adopted the cinematographic metaphor, but derived diametrically opposite conclusions from it. It is worth to quote him in full:

When I first read Bergson's statement that the mathematician conceives the world after the analogy of the cinematograph, I had never seen a cinematograph, and my first visit to one was determined by the desire to verify Bergson's statement, which I found to be completely true, at least so far as I am concerned. When, in a picture palace, we see a man rolling down a hill, or running away from the police $[\ldots]$ we know that there in not really only one man moving, but a succession of photographs, each with a different momentary man. [...] Now what I wish to suggest is that in this respect the cinema is a better metaphysician than common sense, physics, or philosophy. The real man too, I believe, however the police may

${ }^{2}$ Bergson 1922 [1999], p. 141.

Manuscrito - Rev. Int. Fil. Campinas, v. 39, n. 4, pp. 5- 34, out.-dez. 2016. 
swear to his identity, is really a series of momentary men, each different one from the other, and bound together, not by numerical identity, but by continuity and certain intrinsic causal laws. [...] In saying this I am only urging the same kind of division in time as we are accustomed to acknowledge in the case of space. ${ }^{3}$

Russell's view is best represented by his famous theory of motion. "We must entirely reject the notion of a state of motion", he wrote: "motion consists merely in the occupation of different places at different times. There is no transition from place to place, no consecutive moment, or consecutive position, no such thing as velocity except in the sense of a real number which is the limit of a certain set of quotients". ${ }^{4}$ Russell thought that the deflationist understanding of motion afforded by his adoption of Cauchy's and Weierstrass's rigorization of calculus finally allowed us to respond to Zeno's celebrated paradoxes. "Weierstrass", he says, "by strictly banishing all infinitesimals has at last shown that we live in an unchanging world, and that [Zeno's] arrow, at every moment of its flight, is truly at rest". Analogously, since Achilles and the tortoise need not "transit" from one place to the next, nor do they need to reach each position, over and above occupying them at the time that they do, there is no paradox involved in the thought that Achilles can outrun the tortoise.

William James, who (together with Alfred North Whitehead) was the most prominent admirer of Bergson in the Anglo-American scene, disagreed. James observed that classes of things come in two varieties: things conceived as "standing", like space, past times and existing beings;

\footnotetext{
${ }^{3}$ Russell 1918, p. 402.

${ }^{4}$ Russell 1938, p. 473. This deflationist understanding of change and motion had its advocates since memorable times. William of Ockham and his followers advocated a view according to which change is nothing over and above a sequence of different properties had at different times. It was known as the doctrine of changing form (forma fluens), and it opposed the account known as the doctrine of change of form (fluxa formae). According to the latter, when a leaf (for example) changes its color from green to yellow, not only does it have a determinate shade of (say) green at any given time, but, over and above, it also has a changing shade of green.
}

${ }^{5}$ Ibid., p. 347

Manuscrito - Rev. Int. Fil. Campinas, v. 39, n. 4, pp. 5- 34, out.-dez. 2016. 
and things conceived as "growing", like motion, change, activity. ${ }^{6}$ The trouble with Russell's use of Cantor's theory of infinity to dissolve Zeno's paradox of the race, he thought, is that while Cantor and Weierstrass were in the business of providing a theory of the standing (mathematical) variety of infinity, Russell was trying, or should have been trying to give an account of the growing variety, which is necessarily involved in the notions of change and motion.

\begin{abstract}
Mr. Russell's statements dodge the real difficulty, which concerns the 'growing' variety of infinity exclusively, and not the 'standing' variety, which is all that he envisages when he assumes the race already to have been run and thinks that the only problem that remains is that of numerically equating the paths. The real difficulty may almost be called physical, for it attends the process of formation of the paths. 7
\end{abstract}

Once the race has been run, i.e. once the running is past, all that remains of change is a posthumous, changeless bijective correspondence between the mathematical representations of the respective trajectories of Achilles and of the tortoise, which can be perfectly accommodated by Weierstrass' account of limits. But the challenge posed by Zeno's paradox was precisely to explain how such trajectories could be formed, and not how their parts relate to each other after having been already formed (hence assuming that they can be formed).

\title{
1. The Passage of Time and its enemies
}

In all the debates that ensued from this querelle the party of passage accused the other of leaving out something essential to time; something which has to do with its transitory aspect. "Say now and it was even while you say it", quipped William James. Indeed, the idea of time "passing" is deeply entrenched in our cognitive and emotional lives. We say that time passes, that it flows, that it flies. Here today, gone tomorrow. We approach the end

\footnotetext{
${ }^{6}$ Cf. James 1912 [1987], p. 1067

${ }^{7}$ Ibid., p. 1074
}

Manuscrito - Rev. Int. Fil. Campinas, v. 39, n. 4, pp. 5- 34, out.-dez. 2016. 
of the semester, and we are all going to die. The friends of passage speak of the "passing present", "the moving present", the "travelling now", the "passing moment", the "transitory aspect" of time. ${ }^{8}$ All these spatial metaphors make a gesture towards some kind of incessant "motion" of the present time. A gesture towards something which proved extremely hard to be pinned down in clear conceptual terms, and to be made compatible with some of our best scientific theories.

What is the conceptual cash value of these metaphors? What could we possibly mean by saying that time "moves", or that it changes in any way, given that motion and change themselves appear to presuppose a temporal dimension over which variation can occur? Taken literally, these metaphors appear to express either a tautology or an absurdity. To say that the present "moves", in fact, can either mean that different times are present at different times, which is hardly informative; or it can mean that time changes relative to a further temporal dimension, hypertime: a dimension whose sole metaphysical function is to make change of times themselves possible. While some authors tried to make sense of the latter option, it is admittedly awkward, to say the least. Many have argued that the notion of hypertime involves a vicious regress. As Williams put it:

The tragedy then of the extra idea of passage or absolute becoming, as a philosophical principle, is that it incomprehensibly doubles its world by re-introducing terms like "moving" and "becoming" in a sense which both requires and forbids interpretation in the preceding ways. For as soon as we say that time or the present or we move in the odd extra way which the doctrine of passage requires, we have no recourse but to suppose that this movement in turn takes time of a special sort. ${ }^{?}$

Moreover, most philosophers agree that if it made sense to say that time "moves", it would also make sense to ask at what rate it moves: at a rate of, say, one second per... what? Many think that the only sensible answer to this question would be that time passes at a rate of one second per second. And the fact that there do not seem to be other possibilities has been the

${ }^{8}$ Cf. Williams 1951, p. 460-1

${ }^{9}$ Ibid. p. 463

Manuscrito - Rev. Int. Fil. Campinas, v. 39, n. 4, pp. 5- 34, out.-dez. 2016. 
point of departure of many arguments to the effect that time does not really pass. Tim Maudlin, who among B-theorists has been one of the few advocates of the passage thesis, has argued that, while it is true that time could not pass at any other rate but at one second per second, this should not be viewed as a problem:

What exactly is supposed to be objectionable about this answer? Price says we must 'live with the lack of other possibilities', which indeed we must: it is necessary, and, I suppose, a priori that if time passes at all, it passes at one second per second. But that hardly makes the answer either unintelligible or meaningless. ${ }^{10}$

In his Temporal Passage and the 'no alternate possibilities' argument (this issue), Jonathan Tallant, who among A-theorists is one of the few deniers of passage, ${ }^{11}$ argues that Maudlin's view, while not inconsistent or conceptually mistaken, is implausible. After criticizing extant versions of the 'no alternate possibilities' argument, in his essay Tallant puts forward what he takes to be the strongest version of it. Observing that all uncontroversial cases of rates are cases that 'could have other values', Tallant concludes that we have defeasible reasons to believe that time does not pass. Tim Maudlin will respond to this challenge in the second part of this special issue.

The other major difficulty that the friends of passage must face is that passage seems incompatible with Einstein's theory of relativity. After Minkowski's 1908 speech in Cologne, it became clear that relativistic space-time is highly inhospitable to the idea that time can flow, as its geometry does not admit a unique partitioning into sets of simultaneous events. Since most philosophers on both sides of the debate agree that time passes only if the A-theory is true, this has immediately been perceived as a problem (cf. Putnam 1967).

In his Tense, Perspectival Properties, and Special Relativity (this issue), Peter Ludlow puts forward an original view based on the idea that metaphysical tense can be thought of as a kind of perspectival property. He argues that if

\footnotetext{
${ }^{10}$ Maudlin 2007, p. 112.

${ }^{11}$ Cf. Tallant 2010.
}

Manuscrito - Rev. Int. Fil. Campinas, v. 39, n. 4, pp. 5- 34, out.-dez. 2016. 
we incorporate perspectival properties into our semantics, we can uphold to the tenets of the A-theory even in a relativistic spatiotemporal setting.

In as much as Ludlow's proposal concedes that no inertial frame is to be singled out as privileged, it is similar to Kit Fine's Fragmentalism. In his Tense and Reality, Fine defends a view according to which inconsistent Btheoretic relations can all be part of reality.

In order to avoid privileging one frame over another, we take the facts that two events are simultaneous or that either one is earlier than the other to be equally capable of belonging to reality (which, again, is either fragmented or indexed to a frame-time). ${ }^{12}$

Steven Savitt, in his Kit Fine on Tense and Reality (this issue), objects to this concession on the ground that it makes hash of the idea that time passes:

The difficulty with each of these proposals is easily seen in the mere statement of their purpose - to account for the passage of time. Each proposal yields a multiplicity of passages rather than the sought-for unique unfolding of the universe. ${ }^{13}$

Savitt, like Oaklander, believes that passage does not require the reality of tense, but argues that "the proponents of the traditional views $[. .$.$] will$ be unsettled by such multiplicity"14. Can Savitt's objection be raised against Ludlow's proposal too? Prima facie, it appears so, since in Ludlow's spacetime too different B-theoretic relations between the same events are all equally part of reality. Arguably, however, Ludlow's picture has an advantage over Fine's fragmentalism in this respect, since through the proposed semantic realignment, apparently incompatible A-theoretic statements can be viewed as expressing exactly the same thought.

\footnotetext{
${ }^{12}$ Fine 2005, p. 307.

${ }^{13}$ This volume, p. 94.

${ }^{14}$ Ibid., p. 95.
}

Manuscrito-Rev. Int. Fil. Campinas, v. 39, n. 4, pp. 5- 34, out.-dez. 2016. 


\section{McTaggart and his legacy}

In 1908 John Ellis McTaggart published the essay The Unreality of Time. It contained an argument which was to become the most influential point of departure for most debates in the philosophy of time to this day. Together with the debate over the passage of time discussed in the previous sections, the literature on this argument constitutes the other main source of dispute in the contemporary philosophy of time. McTaggart famously argued for two theses.

The first one is the thesis that the series of events which happened, happen and will happen, together with their relative spatiotemporal locations (the C-series), is, in itself, a-temporal, in that it does not instantiate genuine temporal relations of precedence, or simultaneity, in virtue of some intrinsic property of the events themselves, or of the order in which they happen. The events in this a-temporal C-series would instantiate temporal relations only if: (1) they additionally instantiated monadic tense properties (also known as A-properties), pastness, presentness and futurity; and if (2) these properties kept shifting. You were really born after the French Revolution, thinks McTaggart, only if the French revolution was once present while your existence was future, and is now past while your existence is present. Only if time passes, in the sense that events shift continuously their position relative to the present, that is, would the otherwise a-temporal C-series constitute a genuine temporal series (a Bseries), one whose members happen in a temporal sequence, rather than just in a given order.

The second thesis is that it is impossible that events instantiate shifting A-properties. This would require them to inconsistently instantiate each of the incompatible determinations of pastness, presentness and futurity (the A-determinations). It is of no use to insist that these determinations are never had simultaneously. To point out that, for example, the presentness of your existence succeeds that of the French revolution does nothing but repropose at a second order level the same predicament that afflicted us in the first place: it is tantamount to saying that the presentness of your existence was future when that of the French revolution was present etc., and so on ad infinitum.

Manuscrito - Rev. Int. Fil. Campinas, v. 39, n. 4, pp. 5- 34, out.-dez. 2016. 
Thus, since he thought that there can be no time without temporal relations, and no temporal relations without shifting A-properties, and since he further thought that there can be no shifting A-properties, McTaggart concluded that time is not real.

Most views in the contemporary philosophy of time can be usefully classified depending on how they propose to respond to this controversial argument. Few philosophers accepted McTaggart's idealistic conclusion. Most of them preferred to accept only one of the two parts of his argument. Those who accepted the first one (no B-properties without shifting Aproperties) tended to deny the conclusion of the second one, i.e. that the idea of shifting A-properties is inconsistent. They are often referred to as the A-theorists, or tense realists. Others - the majority, up to the first half of the $2^{\text {th }}$ Century - preferred instead to deny McTaggart's second tenet, that genuine temporal relations (B-relations) require shifting A-properties to be instantiated. They are known as the B-theorists, or detensers.

Here are three related distinctions in the philosophy of time.

1. First, there is the distinction between (1) those who believe that things change only if reality itself changes, i.e. only if the totality of monadic states of affairs that exists or obtains at a time is different from that which exists or obtains at other times (also known as Dynamicists); and (2) those who think that what states of affairs constitute reality is not something that depends on what time it is, or on any other temporal perspective (the Staticists).

2. Another major divide is that between those who believe that tense predicates, e.g. Present, Past or Future, refer to mind independent properties or aspects of reality, and those who don't. The former thesis is often referred to as the A-theory of time, or Tense Realism, and the now venerable debate over its virtues and shortcomings constitutes one of the major sub-industries in the philosophy of time. Tense Realists disagree about the nature of tense determinations, and even about whether tense predicates should be taken to refer to dedicated tense properties at all. What all Realist conceptions of tense have in common, however, is the contention that tensed propositions (or utterances) do not have tenseless truth-conditions. Anti-realists, 
on the contrary, think that tense determinations merely reflect anthropocentric, mind-dependent or perspectival features of reality (Smart 1949; Grünbaum 1963). They think that the facts that make tensed statements true are reducible to tenseless facts (Russell 1938; Goodman 1966; Quine 1941), or at least that they have tenseless truth-conditions (Mellor 1981; Oaklander 1991).

3. The third divide pertains to the ontology that underlies tense discourse. According to some authors (the Eternalists), past, present and future things and states of affairs, while possibly located at different temporal "positions", all (tenselessly) exist on an equal footing (Oaklander, Sider). ${ }^{15}$ According to their foes (the nonEternalists), on the contrary, the differences between past, present and future experiences reflect ontological distinctions. At the far end of the spectrum of non-Eternalists views is the doctrine of Presentism: the view that, necessarily, it is always true that only present objects and states of affairs exist (e.g. Prior, Bigelow, Crisp, Tallant).

\section{The disregard for transiency in standard responses to McTaggart's argument}

An aspect of McTaggart's argument that has been unfortunately neglected throughout most of last Century's theorizing, is that it makes essential mention of the transitory aspect of time. Remember that McTaggart's contention is that the events in the a-temporal C-series would instantiate temporal relations only if: (1) they additionally instantiated monadic "tense properties" (also known as A-properties), pastness, presentness and futurity; and if (2) these properties kept shifting. In their response to the argument, most authors have traditionally focused their attention on the reality of tense, understood as the reality of the distinction between past, present and future states of affairs, while they played relatively little attention to what part of reality might make these determinations

15 Oaklander expressed reservations about this way of expressing the eternalist doctrine (see Oaklander 2014).

Manuscrito - Rev. Int. Fil. Campinas, v. 39, n. 4, pp. 5- 34, out.-dez. 2016. 
"shifting". ${ }^{16}$ This neglect, though understandable given the apparently insurmountable difficulties involved in the notion of transiency, produced a substantial separation of the two main disputes which we have presented, that over the reality of passage and that over the reality of tense. A separation, which, as it is clear from the contributions to this volume, the contemporary philosophy of time tends to mitigate.

Another (related) aspect of McTaggart's reasoning that has shaped the philosophical debate in the $20^{\text {th }}$ Century, perhaps obscuring interesting alternatives, is his insistence that transiency could only be understood in terms of A-theoretic concepts, i.e. as some kind of shifting of presentness. This feature of his theorizing appears to have been largely accepted by both parties in the debate. Eternalist and Anti-realist ontologies have been perceived by both parties as inhospitable to a Dynamical conception of change, while non-Eternalist and Realist ones as more congenial to it, essentially because Dynamicists tended to affirm, and Staticists to deny, the reality of temporal passage.

Indeed, it is safe to claim that the chief allure of Realist conceptions of tense has been that they promise to be uniquely capable of accounting for the passage of time. ${ }^{17}$ Only if there is an objective (and absolute) distinction between pastness, presentness and futurity, in fact, can one make sense of the notion that those determinations could "change" in any sense, hence for the notion that time "flows". Conversely, if one believes that there is an objective principled distinction between past, present and future states of affairs, it is most natural to assume that she will want to make sense of the notion that these A-determinations shift in some robust sense. What has gone largely unnoticed, however, is that tense realism, per se, is by no means sufficient to make it true that time passes.

${ }^{16}$ This disregard is betrayed, for example, by the frequent mention of the A-series, understood as the unique series of events ordered by their various degrees of pastness or futurity. Clearly, if time passes in an A-theoretic sense, any such partitioning can only exist for a durationless instant, therefore the passage of time cannot be grounded on any such solitary A-series alone: time passes only if there were in reality as many A-series as there were times.

17 See Oaklander's contribution to this issue for an argument to the effect this unwarranted assumption derives from McTaggart's presuppositions that temporal relations are internal (more on this later).

Manuscrito - Rev. Int. Fil. Campinas, v. 39, n. 4, pp. 5- 34, out.-dez. 2016. 
This is particularly clear in those accounts which propose a conceptual reduction of A-determinations. Many Presentists, for example, think that presentness can be reduced to non-temporal concepts such as truth (Crisp 2007), actuality (Bigelow 1991), reality (Prior 1970) or existence (Christensen 1993). According to Growing Block theorists (e.g. Broad 1923; Tooley 1997; Forrest 2004), the passage of time consists in the fact that more of the world comes to be as time goes by. ${ }^{18}$

Now, the bases for the reduction of presentness that these accounts offer do not comprise essentially dynamic elements. Being true, or real, or actual, or being located at the last frontier of existence, etc., in fact, are not essentially dynamic qualities (i.e. qualities that change by their own nature, in and of themselves): something can well be true, or real, or actual, etc., without changing. It follows that these theories, unadorned, are not sufficient to provide us with an account of the passage of time. Even if Adeterminations are construed as irreducible, primitive properties, they can be argued to be essentially changeless.

The concept of presentness, however it is construed, is different from the concept of future pastness or from that of past futurity; and from the fact that a time is present one cannot infer that it will be past, or that any other time will be (or was) present. It follows that the presentness of a time does not suffice, by itself, to convey the information that something (including presentness itself) is changing, or that it will have changed.

It will be immediately objected that, since the passage of time consists of different times being successively present, from the premise that (1) the presentness of a single time doesn't suffice to make it true that time passes, one cannot safely conclude that (2) tensed statements can only express changeless propositions. It may be granted, for example, that the singular proposition that today is present does not suffice to express the fact that time passes; but surely, it will be argued, today's presentness together with the (distinct) proposition that yesterday has been present too should be more than enough to express the fact of passage. What more can one reasonably ask for?

18 Presentness, according to this view, is thus reduced to the notion of reality at the edge of existence.

Manuscrito - Rev. Int. Fil. Campinas, v. 39, n. 4, pp. 5- 34, out.-dez. 2016. 
A-theorists, in fact, often express their commitment to the dynamic nature of time by supplementing their realist accounts of A-determinations with the comparative truth that what is real (or true, or actual, or irreducibly present, etc.) as of the present time is different from what was or will be real as of other times. ${ }^{19}$ Thus, for example, Crisp 2005:

On the version of presentism under consideration, to say that presentness moves along the ersatz B-series is to say something like this:

$\left.{ }^{*}\right)$ The B-series is such that (i) one and only one of its members $t_{\alpha}$ has the property being present, (ii) for every time $t_{1}$ in the series such that $t_{1}$ is earlier than $t_{\alpha}$, WAS [ $t_{1}$ has being present], and (iii) for every time $t_{2}$ in the series such that $t_{2}$ is later than $t_{\alpha}$, WILL[ $t_{2}$ has being present].

Notice, however, that the information that a given event (say yesterday's presentness) is past does not contain the information that something is or was changing (although a proposition to this effect can be arguably inferred from it). One can realize that things are so by noting that the proposition that yesterday is past is logically equivalent to the conjunction of: (1) the Atheoretic proposition that today is present with (2) the B-theoretic proposition that yesterday comes before today (in the B-series). Now, if, as I have argued, proposition (1) can be made true by a changeless fact, then surely its conjunction with the obtaining of the B-theoretic (hence changeless) relation expressed by proposition (2) can be made true by a changeless fact too. ${ }^{20}$

Another way to expose the essential changelessness of A-theoretic facts is by noting that past tense propositions express truths which obtain in the present. The pastness of yesterday's presentness, for example, is simultaneous with today's presentness: they are both present facts. Of course this is not to say that yesterday is simultaneous with today, which would be absurd: what is simultaneous is the current fact that yesterday's presentness is past and the current fact that today is present. Now, how can the obtaining of two simultaneous changeless (albeit A-theoretic) facts make

${ }^{19}$ Cf. Skow 2012: 224.

${ }^{20}$ This point was made by Fine 2005, p. 287.

Manuscrito - Rev. Int. Fil. Campinas, v. 39, n. 4, pp. 5- 34, out.-dez. 2016. 
it true that time passes? Put more metaphorically, both today's current presentness and yesterday's (current) pastness can be viewed as simultaneous A-theoretic "snapshots", since they presuppose that a particular position within the A-series has been reached, and provide us with an instantaneous, albeit A-theoretic, "picture" of reality as seen from that position. How could any instantaneous snapshot of reality, or any static (i.e. B-theoretic) sequence of similar snapshots, for that matter, make it true that time passes?

We are tricked into thinking that irreducible tense properties are immune from the charge of changelessness because we tend to read more into the Realist contention that there are past states of affairs than it actually conveys. We assume that if something is (already) past it must have become past first. While this assumption may be correct, however, the proposition that an event is past does still not convey the same thought as the proposition that that event was becoming past, when (or before) it became past. ${ }^{21}$

As Oaklander has pointed out:

since on Crisp's view all times are present at the time they are regardless of what time it is, there is no basis or ground in the ersatz B-series for picking out one and only one time that has the property of being present to the exclusion of all earlier and later times that are (tenselessly) also present at their own respective time $[\ldots] .22$

The disregard of A-theorists for the fact of transiency is particularly clear in Crisp's response to Oaklander:

Imagine someone trying to argue against actualism in the same vein. Actualists, they say, hold that one and only one world W1 has the property being actual but that for some distinct world W2 logically accessible from W1, POSS[W2 has being actual]. But this won't do, says our objector, because if W1 has being actual and POSS[W2 has

${ }^{21}$ See my Boccardi 2015 for an analysis of the essential changelessness of Atheoretic facts.

22 Oaklander 2010, p. 236.

Manuscrito - Rev. Int. Fil. Campinas, v. 39, n. 4, pp. 5- 34, out.-dez. 2016. 
being actual], then, contrary to actualism, both W1 and W2 have being actual. This isn't an impressive objection to actualism. But is it interestingly different than objecting to presentism by claiming that if $\left(^{*}\right)$ is true, then every abstract time has each of the A-properties?23

It is interestingly different, I argue! It is, at least, if one wishes to incorporate the idea that which states of affairs happen to be present is a matter that keeps changing. Possible worlds, unlike times (which must become past), are not required to become real, and the actual world is not required to become merely possible. That's why that argument is unimpressive.

Indeed, M. J. Cresswell proposed a modal version of McTaggart's argument, very much in line with that which Crisp has ridiculed. It was devised to show that primitive modality is unreal, just like McTaggart had tried to show that time is unreal. Here is how it goes:

Many M-positions are incompatible with each other. An event which is merely possible for example cannot also be actual. Being merely possible and being actual are mutually incompatible properties of things and events. But because they are contingencies everything has to have them all. Everything occupies every M-position from merely possible to actual. But nothing can really have incompatible properties, so nothing in reality has modal properties. M-positions are a myth. ${ }^{24}$

This argument is appropriate to expose the essential role of the transitory aspect of time in McTaggart's reasoning. As Heather Dyke has rightly observed:

In seeking to construct a modal analogue of McTaggart's paradox, Cresswell faltered when it came to invoking a modal analogue of the continual change of tense that events undergo. He appealed to the 'contingency' of modal properties, but it clearly does not validate the analogous modal inference. Thus, this modal analogue of McTaggart's paradox fails to force one into the position either of

${ }^{23}$ Crisp 2005, my emphasis.

${ }^{24}$ Cresswell 1990, pp. 165-6. Quoted in Dyke 1998, p. 102.

Manuscrito - Rev. Int. Fil. Campinas, v. 39, n. 4, pp. 5- 34, out.-dez. 2016. 
rejecting modality as incoherent (as McTaggart rejects tense as incoherent) or of adopting modal realism (as Mellor adopts tenseless time). It fails, I believe, because there is no clear modal analogue of the change of tense that events and times appear to undergo. ${ }^{25}$

\section{Is there a substantial issue at stake?}

One of the consequences of the above mentioned disregard has been a focus on the semantic aspects of the debate in most of last Century's theorizing. Can statements involving tense predicates be translated into statements which don't? For a long time, the difficulties in providing adequate B-theoretic paraphrases for A-theoretic claims has been perceived by all parties as a threat to the B-theory. This semantic take in the philosophy of time has tended to fade after the metaphysical turn. ${ }^{26}$ One of its legacies, however, has been the suspicion that the A-/B-theory divide doesn't really reflect substantially different metaphysical worldviews. ${ }^{27}$ In his Presentism and the Sceptical Challenge (this volume) Giuliano Torrengo argues that we should take careful notice to this air of insubstantiality of the debate. He sets a number of constraints which Presentism must satisfy, if it is to advance a worldview that is substantially distinguishable from Eternalism.

\section{The A-, the B- and the R-theory of time}

According to McTaggart 1908, we have seen, the non-temporal ground of time is a series of events existing eternally with an intrinsic order, but no intrinsic sense: the C-series. Only the motion of a shifting now could make this series genuinely temporal, since only a shifting now would provide grounds for the relations between these events being genuinely B-theoretic.

\footnotetext{
25 Dyke 1998, p. 103.

${ }^{26}$ A step in this direction was the endorsement by many B-theorists of the New Btheory of Time (cf. Oaklander 1991).

${ }^{27}$ Cf. Williams 1996, Meyer 2005 and Savitt 2006.
}

Manuscrito - Rev. Int. Fil. Campinas, v. 39, n. 4, pp. 5- 34, out.-dez. 2016. 
You were born after the French revolution, not because of some intrinsic feature of either the revolution or your birth, or of the times at which these events occurred, or of some relation induced by the order which the series instantiates. It was the marching present, which at some point enlightened the revolution (pun not intended), when your birth was still future, which grounds the fact that your birth occurred later than the revolution.

As Oaklander has observed several times, this presupposes that Brelations are internal relations. ${ }^{28} \mathrm{He}$ thinks that, if correctly understood, the Russellian stance should be interpreted instead as viewing B-theoretic relations as external and irreducible (he calls them R-relations). Mc'Taggart's failure to appreciate this point is crucial in the derivation of his idealistic conclusion. The same failure on the part of most B-theorists, Oaklander thinks, is also responsible for one of the most serious weaknesses of the standard Eternalist worldview: it is the juncture at which it offers the flank to the accusation of leaving out the essentially dynamic aspect of time.

As Oaklander pointed out to me in personal communication:

I would agree that B-theoretic relations are changeless $[\ldots]$ but it does not follow, at least on the R-theory, that the relations are static and not dynamic. We are given flow, passage, whoosh or whatever in our experience, so why not say that the R-relation (the sequence) is itself the ground of the dynamism? Admittedly, R-facts do not change since like all facts, they are not in time, but that is compatible with their being temporal facts in virtue of containing temporal (dynamic, transitions from earlier to later) relations.

In his Commonsense, Ontology and Time (this volume), Oaklander expands on the R-theory of time, and uses it to criticize Lynne Baker's version of tense realism. In The Metaphysics of Everyday Life, Lynne Baker, who in the past advocated the unreality of tense, argues that what is manifest in everyday life, language and experience should be given full ontological status

\footnotetext{
${ }^{28}$ Following Russell, we shall say that the relation between two objects is internal if there is "something in the natures of the two objects, in virtue of which they have the relation in question"; while it is external if it "cannot be reduced or inferred from, a fact about the one object only together with a fact about the other object only" (Russell 1966, pp. 139-40). Cf. Oaklander 2015.
}

Manuscrito - Rev. Int. Fil. Campinas, v. 39, n. 4, pp. 5- 34, out.-dez. 2016. 
as "irreducibly real." Baker now thinks that among these manifest features we should count both B-theoretic relations and A-theoretic facts. While she agrees with Grünbaum and Russell in viewing tense properties as "mind dependent", she argues that

'nowness' is a product of self-consciousness, but no less part of the reality of time for all that $[\ldots]$. The world that we interact with is ordered temporally by both the B-series and the A-series. ${ }^{29}$

Baker thus proposes a hybrid view, which she calls the AB-theory, according to which the world comprises both irreducible B- and A-theoretic elements. Oaklander argues that Baker's insistence that there be an ontological counterpart to passage which transcends the B-structure derives from a failure to appreciate the true nature of $\mathrm{R}$-theoretic relations. $\mathrm{R}$ relations are temporal because they are inherently and irreducibly dynamic.

This first part of the special issue also features another broadly Russellian response to McTaggart's argument: Erwin Tegtmeier's Time and Order. After advancing an interesting analysis of the concept of order, Tegtmeier reaches a conclusion that agrees with Oaklander's:

\begin{abstract}
McTaggart's argument against the ontological analysis of temporal passage by relational facts is that relational facts do not change while the earmark of time is change. The argument rests on two category mistakes. Firstly, relational facts are used by Russell to analyze change. Therefore, it does not make sense to allow for changing facts $[\ldots]$. Secondly, time is the basis of and thus must not change itself. Time itself is the only respect in which no change is possible. ${ }^{30}$
\end{abstract}

\title{
6. The New Mc'Taggart
}

The never-ending interest in McTaggart's argument has recently resurged, as a number of authors proposed versions of it which appear more aware of the problems that I have been outlining. What they have in

\footnotetext{
${ }^{29}$ Baker 2007, p. 153.

30 This volume, p. 164-5.
}

Manuscrito - Rev. Int. Fil. Campinas, v. 39, n. 4, pp. 5- 34, out.-dez. 2016. 
common is the thought that passage requires more than the presentness of a single moment of time.

Kit Fine proposed a version of McTaggart's argument which consists in showing that Tense Realism is incompatible with three other doctrines about the nature of reality and time. These are: (1) the view that there is never a time (the present) for which the totality of tensed facts are ones which obtain just at that time (Neutrality); (2) the view that the constitution of reality by the facts is an absolute matter, i.e. one that does not depend on any standpoint or perspective (Absolutism); and (3) the view that reality is consistent, that it is not constituted by incompatible facts (Coherence). This is how Fine proposes to derive the incompatibility between these doctrines and tense Realism:

It follows from Realism that reality is constituted by some tensed fact. There will therefore be some time $t$ at which this fact obtains. Now Neutrality states that reality is not oriented towards one time as opposed to another. So reality will presumably be constituted by similar sorts of tensed facts that obtain at other times (given that there are other times!). We wish to show that it then follows that reality will be constituted by incompatible facts [...] If, for example, [reality] allows for the present fact that I am sitting, then it should also allow for the subsequent fact that I am standing. By Absolutism reality is absolutely constituted by these facts; and this is then contrary to Coherence. ${ }^{31}$

Tense realists naturally respond to this challenge by denying Neutrality. Presentists, for example, claim that the totality of facts which constitute reality are always ones which obtain only at the present time: only present facts are lit by the light of reality. Growing blockers claim that the present is that solitary time which stands at the advancing edge of all the facts which obtain or have obtained. Advocates of the moving spotlight view think that, although all the facts which have obtained, which obtain and which will obtain are real, it is always the case that only one time is lit by the light of presentness. What all these views have in common is the contention that the passage of time consists in the continuous shifting of that always solitary

${ }^{31}$ Fine 2005, p. 272.

Manuscrito - Rev. Int. Fil. Campinas, v. 39, n. 4, pp. 5- 34, out.-dez. 2016. 
time which happens to be present. Having denied Neutrality, tense realists may think that they can then safely escape from Fine's McTaggart and commit to the (intuitive) doctrines of Absolutism and Coherence.

Fine, however, like all proponents of the New McTaggart, argues that the view that reality is oriented towards a privileged present time (borrowing Price's terminology, let us call this doctrine Exclusivity) is incompatible with a consistent account of temporal passage. Assuming that an argument against Exclusivity is eo ipso an argument in favor of Neutrality, he then concludes that tense realists - if they want to retain the chief raison d'etre of their doctrine, i.e. the capacity to accommodate for the passage of time should be better advised to abandon either Absolutism or Coherence. ${ }^{32}$

Abandoning Absolutism gives rise to a view which Fine calls External Relativism: the view that which facts constitute reality is a matter that is irreducibly relative to a perspective. Denying Coherence, instead, gives rise to a doctrine according to which reality is (absolutely) composed by mutually incompatible facts (Fragmentalism). Either option commits the Realist to endorse Neutrality: for the External Relativist, each time must be thought of as objectively present relative to that time, while for the Fragmentalist each time is objectively present simpliciter. As Fine puts it, under these non-standard versions of Realism, "presentness is not frozen on a particular moment of time and the light it sheds is spread equitably throughout all time". 33

In his contribution to this issue, Steven Savitt argues that Fine's Fragmentalism does not evade the problem of changelessness. In a sense, Savitt turns Fine's own reasoning against Fragmentalism itself. Here is how Fine expresses the difficulty faced by standard realists:

The standard realist faces a general difficulty. For suppose we ask: given a complete tenseless description of reality, then what does he need to add to the description to render it complete by his own lights? The answer is that he need add nothing beyond the fact that a given time $t$ is present, since everything else of tense-theoretic interest will follow from this fact and the tenseless facts. But then

\footnotetext{
${ }^{32}$ In my Boccardi 2015 I have argued that this assumption is unwarranted.

${ }^{33}$ Ibid., p. 288.
}

Manuscrito - Rev. Int. Fil. Campinas, v. 39, n. 4, pp. 5- 34, out.-dez. 2016. 
how could this solitary 'dynamic' fact, in addition to the static facts that the anti-realist is willing to accept, be sufficient to account for the passage of time? ${ }^{34}$

Savitt argues that Fine's juxtaposition of many such solitary "dynamic" facts does nothing to alleviate the difficulty:

what is more (or less) dynamic in the set of tensed facts or events like $\mathrm{t}$ is present ordered by the is later than relation than is to be found in the sets of simultaneous tenseless facts or events ordered in the same way (successively) by the same relation? Nothing, I submit. ${ }^{35}$

On a similar vein, other authors have argued that passage requires more than the presentness of a single moment of time, that transitions "seem to involve a relation between equals, a passing of the baton between one state of affairs an another"36; but, unlike Fine, they drew from them the conclusion that we should endorse an anti-realist conception of passage (Oaklander, this issue); or, even more radically, that we should opt for a "Copernican shift" and deny the reality passage altogether (Price 2011).

Drawing from Lewis' analysis of change (Lewis 1976), Donald Baxter, in his Aspects and the Alteration of Temporal Simples (this issue), derives a rendition of McTaggart's argument that is in tune with these observations:

Only persisting things can alter. Moments are instantaneous so do not persist. If instantaneous moments were future, then present, then past then something that does not persist would alter. So moments are not future, then present, then past. ${ }^{37}$

The thought behind this argument is that times could change only if they could persist, but since they don't, they cannot change in any respect. Baxter appeals to the theory of aspects to rebuke this rendition of the argument. He concludes that: "the alteration of temporal simples does not require that

\footnotetext{
${ }^{34}$ Ibid., p. 287.

35 This volume, p. 87.

${ }^{36}$ Price 2011, p. 279.

${ }^{37}$ This volume, p. 170.
}

Manuscrito - Rev. Int. Fil. Campinas, v. 39, n. 4, pp. 5- 34, out.-dez. 2016. 
the simple exist at different moments and not be simple. It just requires that the tense aspects of the temporal simple be coordinated with the presenttense aspects of successive moments". 38

Baxter's views bear substantial resemblances with Ludlow's perspectivalism. It would be interesting to explore further how Baxter's aspects relate to Ludlow's perspectives, and if his theory of aspects too could be deployed in a defence of tense realism in a relativistic setting, but this falls beyond the scope of this introduction.

\section{The experience of time}

Why do we think that the present picks out a unique, distinguished time, at the expense of all others? And why do we think that this time keeps changing? Even Einstein was initially reluctant to give in to the Minkowskian interpretation of his theory of relativity, since it threatened to make hash of this deeply entrenched intuition. Carnap reports that even later in his life Einstein was deeply dissatisfied with the fact that physics wouldn't do justice to our experience of the now. ${ }^{39}$ As one of the staunchest deniers of passage admitted, "we are immediately and poignantly involved in the jerk and whoosh of process, the felt flow of one moment into the next". ${ }^{40}$ It has always seemed natural to say that the view that time passes is the best explanation for this immediate phenomenological datum. Is it?

In his contribution to this issue, Oaklander offers a critique of Baker's Moorian defence of the evidential base of the A-theory. After articulating the different stances that we make take vis a vis the metaphysical import of phenomenological data, Oaklander concludes that Baker's insistence that we concede ontological citizenship to A-theoretic determinations is misplaced. Baker, he claims, shares with McTaggart (and many others) the mistaken assumption that the series of events which grounds the B-series is, in itself, non temporal, or static.

\footnotetext{
${ }^{38}$ Ibid., p. 180.

${ }^{39}$ Carnap 1963, pp. 37-38

40 Williams 1951, p. 466.
}

Manuscrito - Rev. Int. Fil. Campinas, v. 39, n. 4, pp. 5- 34, out.-dez. 2016. 
Kriestie Miller and Jane Weiling Loo, in their Presentism, Passage, Phenomenology and Physicalism (this volume) offer a different critique to the idea that the A-theory is mandated by our experience of time. While remaining neutral as to the direct metaphysical import of our temporal phenomenology, they argue that our phenomenology favours presentism only if physicalism is false. Since most philosophers are not prepared to jettison physicalism, their argument constitutes a serious challenge to all phenomenological routes to the A-theory.

\section{Time, Freedom and the Openness of the Future}

One of the chief assets of the A-theory of time is that it promises to do justice to the intuition that the past is substantially different from the future, in that the past is fixed and done with, while the future is somewhat open. This is supposed to be a necessary precondition for retaining a robust sense of freedom in human action. If the future is just as fixed and done with as the past is, it seems, then no one could be held responsible for his or her actions. If Jack the Ripper was fated to commit his horrible crimes since before he was even born, then it seems like any moral judgement about these actions is doomed to be irrational, since he was never really free to do otherwise.

Analogously, it has often been argued that the B-theory of time is more hospitable to the Humean view of natural laws, according to which the laws supervene on the totality of non-modal facts. This, in turn, has been seen as a shortcoming of the B-theory, since it appears to be at odds with the idea that the future is open.

In his Fatalism as a Metaphysical Thesis (this issue) Ulrich Meyer argues that this common preconception against the B-theory of time is misconstrued. After a careful analysis of the notion of predetermination of events, Meyer argues that the idea that some (or all) of our actions are fated is neutral with respect to the underlying ontology of time. He thereby concludes that the doctrine of fatalism should not be of any concern to the metaphysician. The future needs not be open in the metaphysical sense for agents to be free.

Francesco Orilia (this issue) disagrees. In his On the Existential side of the Eternalism-Presentism Dispute he defends the view that Presentism is uniquely

Manuscrito - Rev. Int. Fil. Campinas, v. 39, n. 4, pp. 5- 34, out.-dez. 2016. 
capable of making room for a morally and emotionally relevant openness of the future. He concludes that:

to the extent that we cherish a vision of ourselves as free agents capable of at least partially shaping the future with our own choices, hopefully contributing to make the world a better world, we could emotionally be driven away from an eternalist world and prefer a presentist one. ${ }^{41}$

Marius Backmann (this issue) agrees with Orilia. He submits that it is a desideratum of any view of laws, that they should accommodate for the fact that the future is open in a sense that cuts some ice. In his I tensed the laws and the laws won - non-eternalist Humeanism he advances a view of laws that is Humean in outline, but which is compatible with the A-theory of time. He argues that this view is exempt from standard objections.

\section{Time and Death}

A related debate over the respective virtues of Eternalism and Presentism is that over the value of death. Since antiquity, it was noted that we fear death, which is our future non existence, but we don't appear to have a similar attitude towards the symmetric phenomenon of our prenatal non existence. Now, within an A-theoretic framework, this asymmetry may be justified by the observation that, unlike our past non existence, our future non existence lies ahead of us. The day of our death is dreadfully approaching us. None of this appears to make sense in an Eternalist universe. As Orilia has observed in his contribution to this volume, some may even argue that for this reason, endorsing an Eternalist ontology can help us to "tame our fear of death and to ground our desire to see as preserved what we value most; and, on the other hand, may contribute to discipline any Kierkegaardian anxiety that might seize us in deliberation". ${ }^{42}$

\footnotetext{
${ }^{41}$ This volume, p. 250.

42 This volume, p. 250.
}

Manuscrito - Rev. Int. Fil. Campinas, v. 39, n. 4, pp. 5- 34, out.-dez. 2016. 
In his Fear of Death and the Symmetry Argument (this issue), Gal Yehezkel argues that these presumed implications of the metaphysics of time for the rational appraisal of our asymmetric attitudes towards death and birth are misplaced. He argues that these attitudes should be rather seen as grounded on contingent facts about the processes of birth and death themselves:

While birth is viewed as a nomologically necessary condition for life, and therefore is seen as a blessing, death is viewed as a nomologically unnecessary, and therefore possibly avoidable, limit to life. This asymmetry not only explains the fear of death, and the joy of birth, but also justifies these basic human attitudes. ${ }^{43}$

Natalja Deng's contribution to this issue contains a critique of Yehezkel's stance. She objects that there is no reason to think that birth is more nomologically necessary than death. Her considerations intriguingly invite us to ask, not why we fear death, but rather "why we shouldn't fear prenatal nonexistence too." ${ }^{44}$

\section{Time and Aesthetics}

The implications of the philosophy of time for morality, human existence, freedom or the fear of death (and viceversa) have been debated for thousands of years. An aspect of the debate that has been relatively neglected regards the implications of the philosophy of time for the field of Aesthetics (and viceversa). The closing two essays of this first part of the special issue promise to make up for it.

Storrs McCall (2010) proposed an argument devised to show that backward time travel is impossible, even in circumstance that do not involve changing the past. The argument proceeds from contemplating an imaginary scenario in which a renowned artist copies his paintings from reproductions of his own future paintings. McCall notes that in such a scenario there is no room for the role of the artist's creativity. But since "the aesthetic value of a

\footnotetext{
43 This volume, p. 295.

44 This volume, p. 303.
}

Manuscrito - Rev. Int. Fil. Campinas, v. 39, n. 4, pp. 5- 34, out.-dez. 2016. 
work of art [...] lies in the artistic creativity that produces it" ${ }^{\prime 5}$, he concludes that time travel is not possible after all.

After considering various options, Emily Caddick Bourne and Craig Bourne, in their contribution to this issue, offer a solution to McCall's puzzle which allows us to maintain that the value of works of art is related to the creative process which produced them, while making room for the possibility of time travel. Their solution involves questioning the assumption that, in the envisaged scenario, there would be no room for creativity. While this solution is interesting in its own right, it also offers original insights to the field of Aesthetics, in that it casts new light onto the relation between copying and creativity. In the introduction to a collection of his papers, McCall offered a prize for a solution to his puzzle. "We eagerly await our fortune", conclude the authors. McCall disagrees with the authors. His response will appear in the second part of this special issue.

As we have discussed at the beginning of this introduction, the cinematographic metaphor played an important role in the development of our understanding of time at the beginning of last Century. An aspect that has been less explored regards the implications of the philosophy of time for our understanding of cinematographic fiction. In his contribution to this issue, Robin Le Poidevin considers the question of whether the way in which we think time actually is should influence the way in which we experience time in fiction. If, for example, we are open future theorists, he asks, should we take the fictional future to be open? Le Poidevin considers various ways in which our conceptions of real time and fictional time may match or fail to do so. Interestingly, his considerations lead him to draw a conclusion about the modal status of the A-theory of time:

the abandonment of a fictional past, present and future does not seem to prevent us from treating fictions as temporally structured. That is, we can imagine a time series in ways not defined by a past, present and future. We can, as it were, view fictional time from a 'God's eye' perspective. That suggests that it is not, after all, an essential feature of time that it passes, or has a present which marks the boundary between a determinate past and an indeterminate

45 McCall 2010, p. 647.

Manuscrito - Rev. Int. Fil. Campinas, v. 39, n. 4, pp. 5- 34, out.-dez. 2016. 
future. Perhaps, even if time is structured in this way, this is, like its geometry, a contingent feature. ${ }^{46}$

\section{Concluding remarks}

I have argued that there has been a tendency in the philosophy of time to separate the debate over the reality of temporal passage from the debate over the reality of tense. This has obscured potentially relevant aspects of the metaphysical nature of time. One of the aims of this volume was to bring these two issues together, where they belong. I think many contributions to it go in the right direction.

Moreover, a number of essays in this first part of the issue fruitfully bring metaphysics and other domains of philosophical enquiry together. Robin Le Poidevin, Emily Caddick Bourne and Craig Bourne were able to derive interesting Metaphysical considerations from issues which pertain to the field of Aesthetics; Francesco Orilia from considerations pertaining to Moral Philosophy; Kristie Miller and Jane Weiling Loo from the Philosophy of Mind; Gal Yehezkel and Natalja Deng from the need to rationalize our fear of death. I take this to show that, notwithstanding some opinions to the contrary, contemporary Metaphysics is still big with the future.

\section{References}

Bigelow, J. and Pargetter, R. Science and Necessity, Cambridge: Cambridge University Press. 1990.

Bergson, H. 1998 [1911], Creative Evolution, tr., Arthur Mitchell, New York: Dover.

1999 [1922] Duration and Simultaneity, Robin Durie (ed.), Manchester: Clinamen Press.

Bigelow, J. Worlds Enough for Time, Noûs 25: 1-19, 1991.

${ }^{46}$ This volume, p. 329.

Manuscrito - Rev. Int. Fil. Campinas, v. 39, n. 4, pp. 5- 34, out.-dez. 2016. 
BocCARDI, E. If It Ain't Moving It Shall Not be Moved, Topoi 34 (1): 171185, 2015.

BROAD, C. D, Scientific Thought. New York: Harcourt, Brace, and Company, 1923.

CARnAP, R.. Carnap's Intellectual Biography, in The Philosophy of Rudolf Carnap, P. A. Schilpp (ed.), La Salle, IL: Open Court: pp. 3-84, 1963.

Cresswell, M. J, Modality and Mellor's Mc'Taggart, Studia Logica, 49: 16370, 1990.

CRISP, T. Presentism and the grounding objection, NOÛS, 41(1): 90-109, 2007.

Review of L. Nathan Oaklander, The ontology of time, Notre Dame, $2005 . \quad$ Philosophical Reviews http://ndpr.nd.edu/review.cfm?id=2201.

Christensen, F. Space-like Time, Toronto: University of Toronto Press, 1993.

DyKe, H. Real times and possible worlds, In Robin le Poidevin (ed.), Questions of time and tense, Oxford University Press, 93-117, 1998.

FINE, K. Tense and Reality, in Kit Fine (ed.), Modality and Tense: Philosophical Papers (Oxford: Oxford University Press): 261-320, 2005.

FORREST, P. The real but dead past: a reply to Braddon-Mitchell, Analysis 64: 358-62, 2004.

GoOdman N. The structure of appearance. Bobbs Merrill Co., Inc, Indianapolis, 1966.

Grünbaum, A. Philosophical Problems of Space and Time, New York: Alfred A. Knopf, 1963.

JAMES, W. Writings 1902-1910, Literary Classics of the United States inc., New York, NY, 1987.

Maudlin, T. The Metaphysics Within Physics, Oxford University Press, 2007.

Manuscrito - Rev. Int. Fil. Campinas, v. 39, n. 4, pp. 5- 34, out.-dez. 2016. 
Recent Trends in the Philosophy of Time: an Introduction to Time and Reality I 33

Meyer, U. The Presentist's Dilemma, Philosophical Studies, 122: 213-224, 2005.

MCTAggarT, J. M. E. The Unreality of Time, Mind 18: 457-84, 1908.

MCCALL, S. An insoluble problem, Analysis 70 (4): 647-648, 2010.

MELLOR, D. H. Thank Goodness That's Over!, Ratio 23: 20-30, 1981.

OAKLAnder, N. Temporal Phenomena, Ontology and the R-theory. Metaphysica 16 (2), 2015

Temporal Realism and the R-Theory, in Defending Realism: Ontological and Epistemological Investigations, edited by Guido Bonino, Greg Jesson, Javier Campa, Boston: De Gruyter, 123-139, 2014.

Mc'Taggart's Paradox and Crisp's Presentism, Philosophia, 38: 229241, 2010.

A defence of the New Tenseless Theory of Time, Philosophical Quarterly 41 (162): 26-38, 1991.

Price, H. The Flow of Time, Craig Callender (ed.), The Oxford Handbook of Time, Oxford University Press, 2011.

Prior, A. N. The Notion of the Present, Studium Generale 23: 245-48, 1970.

QuINE, W.V.O. Elementary Logic, New York: Ginn and Co., 1941.

Russell, B. Principles of mathematics, W.W. Norton \& Company, inc, New York, 1938.

Mysticism and Logic and Other Essays, New York, London: Longmans, Green \& Co., 1918.

The Monistic Theory of Truth, In Philosophical Essays, 131-46. London: George Allen \& Unwin Ltd., 1966.

SavitT, S. Presentism and Eternalism in Perspective, in The Ontology of Spacetime, Vol 1, Dieks, D. (ed.), pp 111-127. Amsterdam, The Netherlands and Oxford, UK; Elsevier, 2006.

Manuscrito - Rev. Int. Fil. Campinas, v. 39, n. 4, pp. 5- 34, out.-dez. 2016. 
SmarT, J. J. C. The River of Time, Mind 58: 483-94, 1949.

TAllant, J. A Sketch of a Presentist Theory of Passage, Erkenntnis 73: 133-140, 2010.

Tooley, M. Time, Tense, and Causation, Oxford University Press, 1997.

Williams, D.C. The Myth of Passage, Journal of Philosophy 48: 457-72, 1951.

Williams, C. The metaphysics of a- and b-time, Philosophical Quarterly 46 (184): 371-381, 1996.

Manuscrito - Rev. Int. Fil. Campinas, v. 39, n. 4, pp. 5- 34, out.dez. 2016. 